\title{
Teeth as indicators of exposure of children to lead
}

\author{
DAVID J. STEWART \\ From the Department of Child and Preventive Dentistry, The Queen's University, Belfast
}

\begin{abstract}
Stewart, D. J. (1974). Archives of Disease in Childhood, 49, 895. Teeth as indicators of exposure of children to lead. Deciduous molars, extracted from a total of 310 children aged between 3 and 10 years who resided in urban, suburban, and rural environments in Northern Ireland, were analysed for lead by atomic absorption spectrophotometry.

Tooth lead content increased with age and was influenced by the nature of the donor's environment. Lead concentrations were greatest in the teeth of children in the urban group and least in the rural group, with suburban specimens intermediate.

Deciduous teeth, available in quantity due to the high prevalence of dental caries, can conveniently be used as indicators of the past exposure of children to lead contamination. The analytical method is suitable for use on a sufficient scale to enable comparisons to be made between communities.
\end{abstract}

The amount of lead to be encountered in the environment has given rise to concern in several regions. This paper examines a convenient method whereby its uptake by children might be monitored.

Lead behaves like calcium and most absorbed lead accumulates in bones and teeth. Lead in bone is mobile and subject to loss during the processes of remodelling and mineral withdrawal to meet physiological needs. In teeth, on the other hand, lead deposits are virtually permanent. (Strehlow and Kneip, 1969, for example, found the lead content of teeth of mature subjects to be considerably greater than that of bones.) Tooth analysis therefore can provide retrospective information concerning lead exposure, and of a kind that is not obtainable from other tissues.

Needleman, Tuncay, and Shapiro (1972) found lead levels in the teeth of children in the 'lead belt' of urban Philadelphia greatly in excess of those who resided in suburban areas. This investigation was undertaken to survey the distribution of lead in the teeth of children in Northern Ireland who were living in differing environments.

\section{Materials and method}

Carious primary molars, extracted from children aged from 3 to 10 years who resided in the areas detailed below, were collected and separated according to their donor's age and into the following three residential groups.

Received 29 April 1974.
(1) An Urban group comprised of teeth from children who resided within a 2-mile radius of Belfast City centre. (2) A Suburban group obtained from residents in suburban areas outside the stipulated 2-mile radius. (3) A Rural group made up of specimens collected from children in country districts remote from the city (Co. Fermanagh).

Any teeth showing more than minimal root resorption were discarded. Specimens for analysis were cleared of all carious tissue using a dental drill, and then oven dried to a constant weight at $105{ }^{\circ} \mathrm{C}$. Weighed individual donor samples were dissolved in a concentrated acid mixture made up of 5 parts nitric : 2 parts perchloric. The resulting solution was diluted approximately $1: 10$, buffered with $0.2 \mathrm{~mol} / 1$. glycine ester hydrochloride and the $p \mathrm{H}$ adjusted to $2 \cdot 2-2 \cdot 8$ with dilute ammonia. Lead was chelated from the solution by the addition of ammonium pyrrolidine dithiocarbamate and the complex extracted into $2 \cdot 4$ dimethyl-6-heptanone. This solution was centrifuged at 3000 r.p.m. and the organic phase used for lead determination by a 403 Perkin Elmer atomic absorption spectrophotometer incorporating a tantalum boat accessory to increase sensitivity. With this apparatus, the accuracy of determinations was considered to be within $\pm 5 \%$.

\section{Results}

Quantitative determinations for lead were carried out on teeth from a total of 310 children. In view of outlying values at the upper end of the measurement scale, data obtained concerning the tooth lead content of specimens were subjected to logarithmic transformation. Results relating to specimens 
TABLE

Tooth lead content in children aged 3-10 years from three areas

\begin{tabular}{|c|c|c|c|c|c|c|c|c|}
\hline & \multicolumn{8}{|c|}{$\begin{array}{l}\text { Age } \\
(\mathrm{yr})\end{array}$} \\
\hline & 3 & 4 & 5 & 6 & 7 & 8 & 9 & 10 \\
\hline \multicolumn{9}{|l|}{ Urban } \\
\hline No. & 15 & 32 & 24 & 23 & 19 & 15 & 13 & 7 \\
\hline$\underset{\text { (antilog) }}{\text { Mean } \log _{10}}$ & $\begin{array}{l}0 \cdot 7378 \\
(5 \cdot 47)\end{array}$ & $\begin{array}{l}0.7537 \\
(5 \cdot 67)\end{array}$ & $\begin{array}{l}0.8089 \\
(6 \cdot 44)\end{array}$ & $\begin{array}{l}0.9022 \\
(7.98)\end{array}$ & $\begin{array}{l}0 \cdot 8959 \\
(7 \cdot 87)\end{array}$ & $\begin{array}{l}0.9679 \\
(9 \cdot 29)\end{array}$ & $\begin{array}{l}1 \cdot 0051 \\
(10 \cdot 12)\end{array}$ & $\begin{array}{l}1 \cdot 1284 \\
(13 \cdot 44)\end{array}$ \\
\hline$\underset{\text { Suburban }}{\text { SD }}$ & $0 \cdot 1882$ & $0 \cdot 1662$ & $0 \cdot 1502$ & 0.2174 & 0.2992 & $0 \cdot 2174$ & 0.2331 & $0 \cdot 1588$ \\
\hline $\begin{array}{l}\text { Nowroan } \\
\text { No. }\end{array}$ & 12 & 18 & 16 & 13 & 7 & 12 & 8 & 5 \\
\hline $\begin{array}{c}\text { Mean } \log _{10} \\
\quad \text { (antilog) }\end{array}$ & $\begin{array}{l}0.5774 \\
(3 \cdot 78)\end{array}$ & $\begin{array}{l}0.6382 \\
(4 \cdot 35)\end{array}$ & $\begin{array}{l}0.7637 \\
(5.80)\end{array}$ & $\begin{array}{l}0.7279 \\
(5 \cdot 34)\end{array}$ & $\begin{array}{l}0.7530 \\
(5 \cdot 66)\end{array}$ & $\begin{array}{l}0.9266 \\
(8 \cdot 44)\end{array}$ & $\begin{array}{r}0.9023 \\
(7.99)\end{array}$ & $\begin{array}{l}1 \cdot 1476 \\
(14 \cdot 05)\end{array}$ \\
\hline SD & $0 \cdot 1793$ & 0.1534 & $0 \cdot 1452$ & $0 \cdot 1554$ & 0.2825 & 0.2163 & $0 \cdot 1196$ & 0.1979 \\
\hline \multicolumn{9}{|l|}{ Rural } \\
\hline $\begin{array}{l}\text { No. } \\
\text { Mean } \log _{10} \\
\quad \text { (antilog) }\end{array}$ & $\begin{array}{c}2 \\
0.0989 \\
(0 \cdot 80)\end{array}$ & $\begin{array}{c}5 \\
0 \cdot 4672 \\
(2 \cdot 93)\end{array}$ & $\begin{array}{c}14 \\
0.4781 \\
(3.01)\end{array}$ & $\begin{array}{c}11 \\
0.6149 \\
(4 \cdot 12)\end{array}$ & $\begin{array}{l}13 \\
0.4841 \\
(3.05)\end{array}$ & $\begin{array}{l}0.6475 \\
(4 \cdot 44)\end{array}$ & $\begin{array}{r}0 \cdot 7994 \\
(6 \cdot 30)\end{array}$ & $\begin{array}{r}0.7990 \\
(6 \cdot 30)\end{array}$ \\
\hline SD & $1 \cdot 0677$ & $0 \cdot 1109$ & 0.4057 & $0 \cdot 2050$ & 0.4252 & $0 \cdot 1632$ & 0.1482 & $0 \cdot 1670$ \\
\hline
\end{tabular}

$\mathrm{SD}$, standard deviation in $\log _{10}$ units; antilog, antilog of mean $\log _{10}$.

contained in each of the three residential groups and subdivided according to donor's age are detailed in the Table.

The lead content of teeth obtained from each of the three areas studied was found to increase with age. The mean (antilog) lead content of specimens from donors aged 4 years, for example, was $5 \cdot 67$, $4 \cdot 35$, and $2 \cdot 93$ p.p.m., increasing to $13 \cdot 44,14 \cdot 05$, and 6.30 p.p.m. in the urban, suburban, and rural groups, respectively. The linear increase in tooth lead concentration in each of the groups with increasing age is set out graphically in the Fig. Regression lines are calculated from the log lead content of all specimens in each district, with the

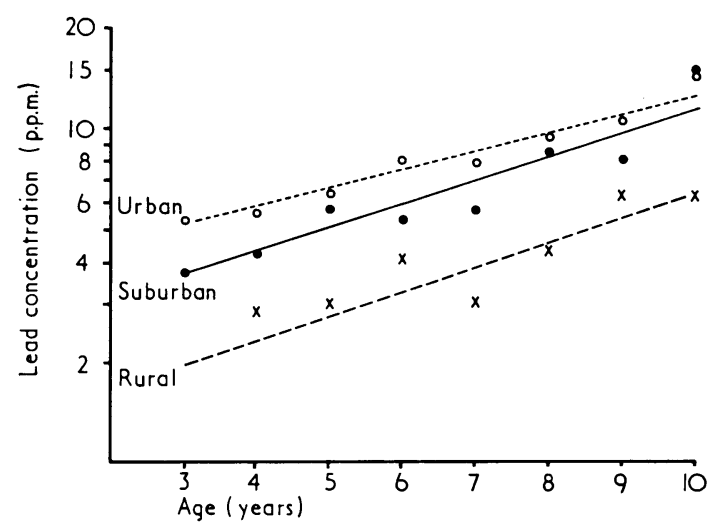

FIG.-The rise in lead concentration (p.p.m.), found in deciduous teeth with increase in age. mean (antilog) value for each age group per district also shown.

Differences between residential groups. The data in the Table enable a comparison to be made between the mean log lead content of teeth from children in the three types of area and for each age group separately. With one exception (groups aged 10 years) these results show that tooth lead concentrations on average were greatest in the urban groups and least in the rural groups, while the average content of the suburban group was intermediate to these two. When a ' $t$ ' test was applied $(P<0 \cdot 05)$, the mean log concentrations found in the urban groups significantly exceeded those of the rural groups at all ages (excluding groups aged 3 years where specimen numbers in the rural group were too few to be helpful), and those of the suburban groups at ages 3,4 , and 6 years, while the mean log concentrations of the suburban groups significantly exceeded those of the rural groups at 4 , 5,8 , and 10 years.

Individual samples of teeth with the highest lead concentrations were found in specimens from the urban children (range $2 \cdot 36-38 \cdot 60$ p.p.m.). Conversely, teeth with the lowest concentrations were found in children in the rural group, all (71) specimens in the latter group having lead below 11 p.p.m. (range $0 \cdot 14-10 \cdot 07$ p.p.m.). Three of the rural specimens obtained from donors aged 3,5 , and 7 years, for example, had lead concentrations near zero $(0 \cdot 14,0 \cdot 15$, and $0 \cdot 2$ p.p.m., respectively) and were the lowest recorded for the entire series. The 
highest value recorded for an individual in the rural group (10.07 p.p.m.) was that of a 7-year-old girl who suffered from Down's syndrome.

\section{Discussion}

Results obtained in this study agree with those of Altshuller et al. (1962), who found that the lead content of primary teeth increases with age and continues to rise after tooth development is complete (primary tooth development is complete by 3 years of age) and, as was also shown so conclusively by Needleman et al. (1972), tooth lead concentration is considerably influenced by the surroundings in which the donors reside. For example, in the latter study which was undertaken in Philadelphia, some children who resided in the 'lead belt' of that city (the district where cases of lead poisoning are most common) were found to have tooth lead levels as high as several hundred parts per million (range $>2-700$ p.p.m.). In comparison with lead concentrations found in the urban children referred to in the American study, levels recorded for Belfast children are low. Of a total of 55 children in urban Philadelphia listed in a graph by the authors, 33 show tooth lead considerably in excess of 25 p.p.m., including 6 children with concentrations lying between 100-700 p.p.m. This contrasts with the Belfast series where only one specimen out of a total of 148 in the urban group was found to have lead greater than 25 p.p.m. (range $2 \cdot 36-38 \cdot 6$ ).

In this investigation the reasons for the greater lead intake by children in the urban group have not been identified, but possible sources include the greater motor vehicle density in the central city area leading to higher atmospheric lead, and its addition to the dust in city streets in which these children often play. Also, a greater proportion of the dwellings in the central area are old as compared with suburban districts, water supplies are soft, and lead in tap water is greater where lead plumbing still exists.

\section{Conclusion}

In view of changing circumstances, it is appropriate that the levels of lead uptake, especially by children, from the environment should be kept under periodic review. Results obtained in this investigation indicate that deciduous teeth, which are readily available in quantity due to the high prevalence of dental caries, can conveniently be used as indicators of the past exposure of children to lead contamination. The analytical method is suitable for use on a scale which is large enough to enable comparisons to be made between communities.

I wish to record my gratitude to Miss $P$. Madden of this department, and to Mr. W. J. Swindall of the Department of Analytical Chemistry, The Queen's University, who carried out the analytical procedures.

$$
\text { REFERENCE; }
$$

Altshuller, L. F., Halak, D. B., Landing, B. H., and Kehoe, R. A. (1962). Deciduous teeth as an index of body burden of lead. Fournal of Pediatrics, 60, 224.

Needleman, H. L., Tuncay, O. C., and Shapiro. I. M. (1972). Lead levels in deciduous teeth of urban and suburban American children. Nature, 235, 111.

Strehlow, C. D., and Kneip, T. J. (1969). The distribution of lead and zinc in the human skeleton. American Industrial Hygiene Association fournal, 30, 372.

Correspondence to Mr. D. J. Stewart, School of Dentistry, The Queen's University of Belfast, Belfast BT12 6BP. 